\title{
Application of the CROPGRO-Soybean Model (DSSAT V 4.5 ) for the Assessment of the Environmental Modification Effect on Soybean Productivity in the Akola region of Vidarbha, India
}

\author{
Anil Nath*, A. P. Karunakar, Sanjay Wanjari and Arvind Kumar
}

Dept. of Agronomy, Dr. Panjabrao Deshmukh Krishi Vidyapeeth, Akola, Maharashtra (444 104), India

\section{Corresponding Author}

Anil Nath

e-mail: anil07nath@gmail.com

\author{
Article History \\ Article ID: AR1865b \\ Received in 09 $9^{\text {th }}$ March, 2018 \\ Received in revised form $27^{\text {th }}$ August, 2018 \\ Accepted in final form $31^{\text {st }}$ August, 2018
}

\begin{abstract}
Soybean is grown predominantly under rainfed conditions where weather variability is high. To analyse the effects of climate change on soybean growth and production, CROPGRO model (DSSAT v 4.5) was applied with four different sowing dates for the diverse environment of akola region of Vidarbha, India. Environmental modification simulated with up scaling of maximum temperature from $1{ }^{\circ} \mathrm{C}$ to $5{ }^{\circ} \mathrm{C}$ decreased the yield by -4.7-50.4\% under $27 \mathrm{MW}$ sowing whereas the magnitude of yield reduction was to a greater degree with delayed $30 \mathrm{MW}$ sowing recorded -8.1 to $78.8 \%$ reduction. The down scaled minimum temperature increased the yield by $+1.2 \%$ at $1{ }^{\circ} \mathrm{C}$ downscale. Subsequently, downscaled minimum temperature by 2 to $5^{\circ} \mathrm{C}$ decreased the seed yield by -2.5 to $-23.7 \%$ under $27 \mathrm{MW}$ sowing whereas downscaled minimum temperature by 1 to $5{ }^{\circ} \mathrm{C}$ decreased the seed yield by -1.6 to $-42.9 \%$ under $30 \mathrm{MW}$ sowing. Simulation of $\mathrm{CO}_{2}$ concentration raised by 100, 200 and to $300 \mathrm{ppm}$, over the base value (392 ppm) increased seed yield by 16.5 to $38.6 \%$ under $27 \mathrm{MW}$ sowing whereas under $30 \mathrm{MW}$, it increased the seed yield only by 12.8 to $30.4 \%$. Elevated $\mathrm{CO}_{2}$ concentration of 100 ppm coupled with elevated maximum temperature level by 1,2 and $3{ }^{\circ} \mathrm{C}$ decreased the yield level by -5.4 to $-25.7 \%$ under $27 \mathrm{MW}$ sowing and -28.4 to -50.8 under $30 \mathrm{MW}$ sowing. Thus overall results show that delay in sowing date in rainfed regions has more negative consequences on soybean productivity under different climate change scenario than early sowing of soybean.
\end{abstract}

Keywords: CROPGRO model, climate change, sowing date, soybean productivity

\section{Introduction}

Soybean [Glycine max (L.) Merrill] ranks firstamong the oilseeds in the world and now it also has been founda prominent place in India as rainfed crop. It is used as a vegetable for human consumption, as oil, or as animal feed. Soybean has a good potential to get involved in the intercropping as well as crop sequences, as it is a short duration (85-125 days) leguminous crop.The fast adaptation of the crop by the farmers in India points out that soybean is going to be the future commercial venture in the country. Soybean is grown predominantly under rainfed conditions where weather variability is high. Particularly the variation in the onset of the monsoon and its seasonal distribution during the crop growing period is largely responsible for the relative performance of the soybean crop. Meotti et al. (2012) observed that $77 \%$ of soybean yield variability is associated with the climate conditions induced by the sowing dates. Being a rainfed crop, sowing time of soybean is largely dependent on the onset of the monsoon. Future climatic changes arealso likely to have substantial impact on soybean production depending upon the magnitude of variation in $\mathrm{CO}_{2}$ concentration and temperature.Plants are affected by different components of global climate change including elevated $\mathrm{CO}_{2}$ (Jablonskiet al., 2002; Norby and Luo, 2004; Ziska and Bunce, 2006) and high temperature (Challinor et al., 2005; K'orner, 2006; Morecroft and Paterson, 2006). Elevated atmospheric $\mathrm{CO}_{2}$ has positive effects on crop growth and productivity. It improve the quantitive as well as qualitive traits by increasing photosynthesis rate and water use efficiency and by decreasing transpiration through reducing stomatal conductance (Long et al., 2004). The potential for crop productivity should increase with increased local average temperature over a range of 1 to $3{ }^{\circ} \mathrm{C}$, but decrease above this range (IPCC, 2007) likely because of poor vernalization (Trnka et al., 2004), shortened phenological stages (Mitchell et al., 1993), decreased photosynthesis and increased transpiration and stomatal conductance (Nobel, 2005). A crop simulation model can be a useful tool to evaluate the potential effects of water deficits and increased temperature on crop yield. During the last 30 years, simulation models have been developed for a number of crop production processes 
including weather, soil erosion, phenology, growth, and yield (Anbumozhi et al., 2003). Singh et al. (2010) conducted an experiment for evaluation of 'SOYGRO' model for soybean and reported that, yield attributes like pods plant ${ }^{-1}$, number of seeds pod $^{-1}$ and 100 seed weight decreased with subsequent delay in sowing from 7 June onward during both the seasons.Alagarswamy et al. (2000) reported that the CROPGRO-Soybean model embedded in DSSAT Vol. 3 can reasonably simulate total biomass and yield of soybean both in moisture deficit tropical situations and in cooler temperate and subtropical locations. Thus several crop models may be used to simulate the effects of elevated $\mathrm{CO}_{2}$ level and temperature change on crop productivity. Crop modeling is a technology that has been applied in precision farming, farm planning and policy development. Crop models can be used to predict yield as well as to evaluate the variability and risks of different management strategies over a range of locations and climatic conditions.CROPGRO-Soybean is a processoriented management level model which has the capability to simulate development, growth and yield under diverse environmental conditions. CROPGRO-Soybean is a part of a suite of crop growth models available in the software named Decision Support System for Agrotechnology Transfer (DSSAT). DSSAT is a suite of crop models integrated into a single software package in order to facilitate the application of crop simulation in research and decision-making. The CROPGROSoybean model requires inputs of management practices and environmental conditions and incorporates knowledge of cultivar-specific traits (genetic coefficients) to predict growth and development as the plant responds to weather, soil characteristics, and management practices (Boote et al., 1998). In order to increase its applicability, there is a need to test its location specific performance. Crop simulation models once calibrated and validated for a particular crop and location have capabilities to predict crop growth response to weather, soils, crop management, and genetic factors. Crop responses to climatic variations like elevated temperature and carbon dioxide level can be predicted by using crop simulation models

The objective of this research was to predict accurate soybean yield under different temperature range and $\mathrm{CO}_{2}$ concentration and to alleviate the climate change impacts on soybean production under different temperature range and $\mathrm{CO}_{2}$ concentration by using CROPGRO-soybean simulation model.

\section{Materials and Methods}

The field investigation was carried out during kharif season of 2014 under the All India Coordinated Research Project on Agro meteorology at Dry land Agriculture Research Centre, Dr. Panjabrao Deshmukh Krishi Vidyapeeth, Akolato simulate soybean yield by using CROPGRO-Soybean model. The place of field investigation is situated in the sub-tropical zone at the latitude of $22^{\circ} 42^{\prime}$ North and longitude of $77^{\circ} 02^{\prime}$ East. The altitude of the place is 307.41 meter above msl. The treatments consisted of four sowing times (27 MW-July 07, $28 \mathrm{MW}$-July 14, $29 \mathrm{MW}$ - July 21 and $30 \mathrm{MW}$-28 July) and three varieties (JS-335, JS-9305 and TAMS 98-21) were laid out in Factorial Randomized Block Design with four replications . Plot size was $4.5 \times 5.0 \mathrm{~m}^{2}$ (Gross) and $3.6 \times 4.6 \mathrm{~m}^{2}$ (Net) with $45 \times 05 \mathrm{~cm}^{2}$ spacing. Gap filling was done on $6^{\text {th }}$ and thinning on $10^{\text {th }}$ day after sowing so as to maintain intra plant spacing of $5 \mathrm{~cm}$. Recommended dose of nitrogen and phosphoruswas applied @ 30:75 ( $\left.\mathrm{N}: \mathrm{P}_{2} \mathrm{O}_{5}\right) \mathrm{kg} \mathrm{ha}^{-1}$ through urea $(46 \% \mathrm{~N})$ and single super phosphate $\left(16 \%, \mathrm{P}_{2} \mathrm{O}_{5}\right)$, respectively at the time of sowing. Adequate agronomic practices were done for good establishment of the plants. The crop data, weather data and physico-chemical properties of the soil were obtained during crop growing season. The soil was clayey, moderately alkaline with medium in organic carbon (Walkely and Black's rapid titration method, Jackson, 1967), low in available nitrogen (Alkaline permanganate method, Subbiah and Asija, 1956) and available phosphorus (Olsen's method, Jackson, 1967) and fairly rich in available potassium (Flame emission photometer, Jackson, 1967). Detailed observations on phenology and crop growth (plant stand, plant height, leaf area, dry matter weight at different stages) and yield measurements were made in individual treatment. Agro-meteorological indices like rainfall distribution, air temperature and relative humidity regime, heliothermal and photothermal units, growing degree days, thermal use efficiency were studied at different phenophase. Moisture use studies (actual crop water use and crop water productivity) were also done after harvest. Validated CROPGRO model (DSSAT v 4.5) was applied to simulate the impact of climate change on soybean growth and production. Model was firstly calibrated and validated against results from soybean trial at Dr. P.D.K.V.,Akola. Paknejad et al. (2012) reported that dynamic models can help to determine the optimum sowing date for soybean crop. For evaluation of soybean simulation by using of CROPGROSoybean model at four sowing date, a field experiment was conducted. The result showed that model was successful in the traits simulation. According to Banterng et al. (2010) CSM-CROPGRO-soybean simulations indicated that the optimum planting dates from June 15 to July 15 produced maximum soybean yield in a rainfed environment.

\subsection{CROPGRO-soybean (DSSAT v 4.5) model}

A detailed soybean growth model, CROPGRO was used to study the impact of climate changes underakola conditions. The CROPGRO-soybean model which share acommon input and output data format have been embedded in a software package called the Decision Support System for Agrotechnology Transfer (DSSAT). The model requires input data on soil, crop andweather for its calibration and validation in differentenvironments. The model operates on a daily time basis. It can simulate crop growth and development of four different legumes (soybean, peanut, common bean, chickpea). A description of the processes in CROPGRO is provided by Boote et al. (1998). The CROPGRO-Soybean model reasonably 
predicts growth and yield in various subtropical and temperate locations. In order to increase its general applicability, models need to be evaluated in diverse conditions. To achieve this, the CROPGRO-soybean model (DSSAT v 4.5) was evaluated for the diverse environment of akola region of Vidarbha, India for the soybean cultivar JS-335, JS-9305 and TAMS 9821. The genetic coefficients of the soybean varieties JS-335, JS-9305 and TAMS 98-21 were determined with the GLUE coefficient estimator embedded in the DSSAT $\vee 4.5$ model by using the data collected during the experiment. It was done by repeated iterations in the model calculationsuntil a close match observed between simulated and observedphenology, growth and yield. Genetic coefficients were used to simulate the response of various cultivars to weather and management conditions. The observed experimental data were compared with the model simulation results. The evaluation of the model on an overall basis revealed that the model simulation performance in respect of phenological phases and yield was found to be reliable. Subsequently, the sensitivity of soybean production to separately changed weather variables was determined.

\section{Results and Discussion}

\subsection{Impact of elevated $\mathrm{CO}_{2}$ and temperature change}

Sensitivity test of the crop simulation model is the process by which various input parameters are evaluated with regards to their importance relative to simulation relations. An effort has been made to test the model under two situations in terms of extreme values of weather parameters viz. elevated $\mathrm{CO}_{2}$ concentration and temperature change under environmental modification to assess its simulated impact on productivity. The weather parameters selected for this purpose were maximum temperature $\left(+1\right.$ to $\left.5^{\circ} \mathrm{C}\right)$, minimum temperature $\left(-1\right.$ to $\left.5^{\circ} \mathrm{C}\right)$ and concentration of carbon dioxide $(+100,+200$ and $+300 \mathrm{ppm})$. The yield variations were compared as \% increase or decrease of model output under normal weather conditions.

\subsection{Environment modification simulated for maximum and minimum temperature change}

The effects of \pm 1 to $5^{\circ} \mathrm{C}$ maximum and minimum temperatures on simulated seed yield of soybean and its \% change of yield from model output under normal weather conditions are presented in Table 1. Sensitivity of CROPGRO (DSSAT) model simulated seed yield to sowing time from $27 \mathrm{MW}$ to 30 MW showed a gradual decrease in yield from 968 to 431 $\mathrm{kg} \mathrm{ha}^{-1}$ underobserved weather conditions (maximum and minimum temperatures) of the year kharif, 2014. The up scaled maximum temperatures gradually decreased the yield by -4.7 to $-50.4 \%$ under $27 \mathrm{MW}$ sowing $\left(D_{1}\right)$. The magnitude of yield reduction was to a greater degree with delayed 30 MW sowing recording -8.1 to $78.8 \%$ reduction with up scaled maximum temperature from $1{ }^{\circ} \mathrm{C}$ to $5{ }^{\circ} \mathrm{C}$. Puteh et al. (2013) noted that high temperature stress during reproductive growth stage in soybean reduced yield components and seed

\begin{tabular}{lccccccccccccc}
\hline Table 1: Environmental modification simulated for maximum and minimum temperature $\left({ }^{\circ} \mathrm{C}\right)$ change \\
\hline Sowing time & 5 & 4 & 3 & 2 & 1 & $\begin{array}{c}\text { Normal yield } \\
\left(\mathrm{kg} \mathrm{ha}^{-1}\right)\end{array}$ & -1 & -2 & -3 & -4 & -5 \\
& & & & & & & & & & \\
\hline $\mathrm{D}_{1}(27 \mathrm{MW})$ & 480 & 569 & 716 & 844 & 922 & 968 & 980 & 944 & 906 & 833 & 738 \\
& $(-50.4)$ & $(-41.2)$ & $(-26.0)$ & $(-12.8)$ & $(-4.7)$ & & $(+1.2)$ & $(-2.5)$ & $(-6.4)$ & $(-13.9)$ & $(-23.7)$ \\
$\mathrm{D}_{2}(28 \mathrm{MW})$ & 298 & 432 & 556 & 618 & 695 & 725 & 717 & 673 & 635 & 577 & 523 \\
& $(-58.9)$ & $(-40.4)$ & $(-23.3)$ & $(-14.7)$ & $(-4.1)$ & & $(+1.1)$ & $(-7.2)$ & $(-12.4)$ & $(-20.4)$ & $(-27.8)$ \\
$\mathrm{D}_{3}(29 \mathrm{MW})$ & 180 & 248 & 315 & 408 & 448 & 510 & 486 & 490 & 410 & 388 & 353 \\
& $(-64.7)$ & $(-51.4)$ & $(-38.2)$ & $(-20.0)$ & $(-12.1)$ & & $(-4.7)$ & $(-3.9)$ & $(-19.6)$ & $(-23.9)$ & $(-30.7)$ \\
$\mathrm{D}_{4}(30 \mathrm{MW})$ & 91 & 143 & 299 & 351 & 396 & 431 & 424 & 388 & 322 & 280 & 246 \\
& $(-78.8)$ & $(-66.8)$ & $(-30.6)$ & $(-18.6)$ & $(-8.1)$ & & $(-1.6)$ & $(-9.9)$ & $(-25.2)$ & $(-35.0)$ & $(-42.9)$ \\
\hline
\end{tabular}

yield. According to Jablonski et al. (2002) soybean and kidney bean seeds increasingly fail to fill properly as temperature increase and form smaller, shriveled seeds with reduced seed germination capability and nutritional quality than under optimum temperature.Kumar et al. (2008) observed that the simulated results indicate that increasing the temperature levels and prolong dry spell could pose a serious threat in the flowering stage, pod setting, growth and the economical yield of soybean. Boote et al. (2002) also noted lower yield in late sown faba bean due to higher temperature and short life cycle. This showed that if global temperature will rise up to $1.0^{\circ} \mathrm{C}$ due to climate change, possibly the crop can perform acceptably, but beyond $1.0^{\circ} \mathrm{C}$ rise in maximum temperature yield reduction was found higher. This suggests that breeding of heat tolerant cultivar should be developed to bridge this yield gap. The down scaled minimum temperatures gradually increased the yield by $+1.2 \%$ at $1^{\circ} \mathrm{C}$ downscale under $27 \mathrm{MW}$ sowing. Subsequently downscaled minimum temperature by 2 to $5^{\circ} \mathrm{C}$ decreased the seed yield by -2.5 to $-23.7 \%$ under $27 \mathrm{MW}$ sowing. The magnitude of yield reduction was to a lesser degree as compared to that under up scaled maximum temperature effects. As such the average maximum and minimum temperature during kharif soybean growing period was 36.4 and $23.8^{\circ} \mathrm{C}$ and the applied downscaling 
minimum temperature might not affect the crop growth and development as to a degree that of upscaling the maximum temperatures beyond the normal favourable range of crop growth and development.

Here the results clearly indicated that up scaled maximum temperature $\left(+1\right.$ to $+5^{\circ} \mathrm{C}$ ) variation had a pronounce effect on seed yield of soybean as compared to down scaled minimum temperatures $\left(-1\right.$ to $\left.-5^{\circ} \mathrm{C}\right)$.

\subsection{Environment modification simulated for elevated carbondioxide}

The effects of elevated carbon dioxide $\mathrm{CO}_{2}(+100,+200$ and +300 ppm from the base value $392 \mathrm{ppm}$ ) on simulated seed yield of soybean as \% increase or decrease of model output under normal conditions have been presented in Table 2 . Results showed that when $\mathrm{CO}_{2}$ concentration was raised by $100 \mathrm{ppm}$ to $300 \mathrm{ppm}$, over the simulation value (392 ppm)

Table 2: Environmental modification simulated for elevated $\mathrm{CO}_{2}$ concentration

\begin{tabular}{lcccc}
\hline Sowing time & \multicolumn{4}{c}{ Seed yield $\left(\mathrm{kg} \mathrm{ha}^{-1}\right)$} \\
\cline { 2 - 5 } & Normal & $+100 \mathrm{ppm}$ & $+200 \mathrm{ppm}$ & $+300 \mathrm{ppm}$ \\
\hline $\mathrm{D}_{1}(27 \mathrm{MW})$ & 968 & 1128 & 1248 & 1342 \\
& & $(16.5)$ & $(28.9)$ & $(38.6)$ \\
$\mathrm{D}_{2}(28 \mathrm{MW})$ & 725 & 847 & 936 & 1012 \\
& & $(16.8)$ & $(29.1)$ & $(39.6)$ \\
$\mathrm{D}_{3}(29 \mathrm{MW})$ & 510 & 603 & 671 & 729 \\
& & $(18.2)$ & $(31.6)$ & $(42.9)$ \\
$\mathrm{D}_{4}(30 \mathrm{MW})$ & 431 & 486 & 527 & 562 \\
& & $(12.8)$ & $(22.3)$ & $(30.4)$ \\
\hline
\end{tabular}

Figures in parentheses are \% variation

the yield increased by 16.5 to $38.6 \%$ under $27 \mathrm{MW}$ sowing. Similarly the yield increase of nearly 12.8 to $30.4 \%$ was observed under $30 \mathrm{MW}$ sowing. According to Prasad et al., (2005) in the absence of biotic (pests, diseases and weeds) or abiotic (temperature, water and nutrients) stresses, elevated $\mathrm{CO}_{2}$ concentration will increase the yield of grain of legume crops (e.g., soybean, drybean, peanut, cowpea) due to increased photosynthesis rate and growth. Singh and Jasrai (2012) reviewed that plant growth, biomass accumulation and net photosynthetic rate have been generally found to increase at high $\mathrm{CO}_{2}$ conditions in wheat, rice, soybean and horticultural crops.Boote et al. (2003) observed similar rise in soybean yield and water use efficiency (WUE) under elevated concentration of $\mathrm{CO}_{2}$ over base $\mathrm{CO}_{2}$. According to Madhu and Hatfiled (2015) plants under elevated $\mathrm{CO}_{2}$ concentration produced significantly greater numbers of root nodules per plant compared with plants under ambient $\mathrm{CO}_{2}$ concentration which indicates that future plants may be benefited from $\mathrm{N}_{2}$ fixation if other environmental conditions are favorable.

3.4. Environment modification simulated for elevated carbondioxide coupled with elevated maximum temperature
The effects of elevated carbon dioxide $(+100 \mathrm{ppm}$ from the base value $392 \mathrm{ppm}$ ) coupled with elevated maximum temperature level $\left(1\right.$ to $\left.3^{\circ} \mathrm{C}\right)$ on simulated seed yield of soybean as $\%$ increase or decrease of model output under elevated carbon dioxide of +100 ppm alone have been presented in Table 3 . When solely $\mathrm{CO}_{2}$ concentration was raised by $100 \mathrm{ppm}$ over the base value in the model, yield increased by $16.5,16.8,18.2,12.8 \%$ across $27,28,29$ and 30 $\mathrm{MW}$ sowings (Table 2 ) . However, elevated $\mathrm{CO}_{2}$ concentration by $100 \mathrm{ppm}$ coupled with elevated maximum temperature

Table 3: Environmental modification simulated for elevated $\mathrm{CO}_{2}$ concentration ( $\mathrm{ppm}$ ) coupled with elevated maximum temperature

\begin{tabular}{lcccc}
\hline Sowing time & \multicolumn{4}{c}{ Seed yield $\left(\mathrm{kg} \mathrm{ha}^{-1}\right)$} \\
\cline { 2 - 5 } & Normal & $+100 \mathrm{ppm}$ & $+200 \mathrm{ppm}$ & $+300 \mathrm{ppm}$ \\
\hline D1 (27 MW) & 1128 & 1067 & 947 & 838 \\
& & $(-5.4)$ & $(-16.0)$ & $(-25.7)$ \\
D2 (28 MW) & 847 & 820 & 726 & 656 \\
& & $(-3.2)$ & $(-14.3)$ & $(-22.6)$ \\
D3 (29 MW) & 603 & 527 & 484 & 373 \\
& & $(-12.6)$ & $(-19.7)$ & $(-38.1)$ \\
D4 (30 MW) & 486 & 348 & 297 & 239 \\
& & $(-28.4)$ & $(-38.9)$ & $(-50.8)$ \\
\hline
\end{tabular}

Figures in parentheses are $\%$ variation

level by 1,2 and $3{ }^{\circ} \mathrm{C}$ decreased the yield level by -3.2 to $28.4 \%$ under $1{ }^{\circ} \mathrm{C}$, by -14.3 to $-38.9 \%$ under $2{ }^{\circ} \mathrm{C}$ and by -22.6 to $-50.8 \%$ under $3{ }^{\circ} \mathrm{C}$ across the 27 to $30 \mathrm{MW}$ sowings. Thus, increasing maximum temperature offset the yield level increase, which was observed solely under elevated $\mathrm{CO}_{2}$ concentration. According to Prasad et al. (2005) the beneficial effects of elevated $\mathrm{CO}_{2}$ concentration are more than negative effects of temperature on yield and yield-components, which lead to lower seed yield. Aiken (2009) also opined that benefits of increased $\mathrm{CO}_{2}$ concentration could readily be offset by increased heat stress. Boote et al. (2005) observed in their study on effect of elevated temperature and $\mathrm{CO}_{2}$ concentrationon reproductive growth and yield of globally important crops that increases in air temperature anticipated with global climate change will adversely impact reproductive processes and seed yield of grain crops and also reported that there are no beneficial interactions of elevated temperature and $\mathrm{CO}_{2}$ concentration. On the contrary, there are indications of negative interactions of elevated temperature and $\mathrm{CO}_{2}$ concentration for species associated with $\mathrm{CO}_{2}$ inducedwhich increases canopy temperature.

\section{Conclusion}

Delay in sowing date in rainfed regions has more negative consequences under different climate change scenario than 
early sowing of soybean. This suggests that breeding of heat tolerant cultivar should be developed to bridge this yield gap. This simulation study also demonstrates that models like CROPGRO-soybean when standardized for a location, can be used for decisions with respect to selection of sowing dates, varieties or to assess the potential yield under different environmental conditions.

\section{Reference}

Aiken, R., 2009. Climate change impacts on crop growth in the central high plains. Proceedings of the $21^{\text {st }}$ Annual Central Plains Irrigation Conference, Colby Kansas, February 24-25, 2009 Available from CPIA, 760 N Thompson, Colby, Kansas.

Alagarswamy, G., Singh, P., Hoogenboom, G., Wani, S.P., Pathak, P., Virmani, S.M., 2000. Evaluation and application of the CROPGRO-soybean simulation model in a Vertic Inceptisol. Agricultural systems 63, 19-32.

Anbumozhi, V., Reddy, V.R., Lu, Y.C., Yamaji, E., 2003. The role of crop simulation models in agricultural research and development: A review. Agricultural Engineering Journal 12(1), 1-18.

Banterng, P., Hoogenboom, G., Patanothai, A., Singh, P., Wani, S., Pathak, P., Tongpoonpol, S., Atic-hart, S., Srihaban, P., Buranaviriyakul, S., Jintrawet, A., Nguyen, T.C., 2010. Application of the cropping system model (CSM)-CROPGRO-soybean for determining optimum management strategies for soybean in tropical environments. Journal of Agronomy and Crop Science 196(3), 231-242.

Boote, K.J., Jones, J.W., Hoogenboom, G., Pickering, N.B., 1998. The CROPGROW Model for grain legumes. In: Tsuji, G.Y., Hoogenboom, G., Thornton, P.K. (Eds.), Understanding Options for Agricultural Production, 99-128.

Boote, K.J., Minguez, M.I., Sau, F., 2002. Adapting the CROPGRO-legume model to simulate growth of faba bean. Agronomy Journal 94, 743-756.

Boote, K.J., Jones, J.W., Batchelor, W.D., Nazfiger, E.D., Myers,O., 2003. Genetic coefficients in the CROPGROsoybean model: links to field performance and genomics. Agronomy Journal 95(1), 32-51.

Boote, K.J., Aleen, L.H., Prasad, P.V.V., Baker, J.T., Gesch, R.W., Snyder, A.M., Pan, D., Thomas, J.M.G., 2005. Elevated temperature and carbon dioxide impacts on pollination, reproductive growth, and yield of several globally important Crops. Journal of Agricultural Meteorology 60, 469-474.

Challinor, A.J., Wheeler, T.R., Craufurd, P.Q., Slingo, J.M., 2005. Simulation of the impact of high temperature stress on annual crop yields. Agricultural and Forest Meteorology 135 (1-4), 180-189.
IPCC (Intergovernmental Panel on Climate Change), 2007: The physical Science Basis. Contribution of working group i to the fourth assessment report of the intergovernmental panel on climate change. In: Solomon, S., Qin, D., Manning, M., Chen, Z., Marquis, M., Averyt, K.B., Tignor, M., Miller, H.L. (Eds.), Cambridge University Press, Cambridge, United Kingdom and New York, NY, USA, 996.

Jablonski, L.M., Wang, X.Z., Curtis, P.S., 2002. Plant reproduction under elevated $\mathrm{CO}_{2}$ conditions: A metaanalysis of reports on 79 crop and wild species. New Phytologist 156 (1), 9-26.

K'orner, C., 2006. Significance of temperature in plant life. In: Morison, J.I.L., Morecroft, M.D. (Eds), Plant Growth and Climate Change. Blackwell Publishing Ltd, Oxford, UK, 48-69.

Kumar, A., Pandey, V., Sheikh, A.M., Kumar, M., 2008. Evaluation of Cropgro-Soybean (Glycine max. [L] (Merrill) Model under varying environment condition. American-Eurasian Journal of Agronomy 1(2), 34-40.

Long, S.P., Ainsworth, E.A., Rogers, A., Ort, D.R., 2004. Rising atmospheric carbon dioxide: plants FACE the future. Annual Review of Plant Biology 55, 591-628.

Madhu, M., Hatfield, J.L., 2015. Elevated carbon dioxide and soil moisture on early growth response of soybean. Agricultural Sciences 6, 263-278.

Meotti, G.V., Benin, G., Silva, R.R., Beche, E., Mumaro, L.B., 2012. Epocas de semeadura e desempenhoagronomico de cultivares de soja. Pesquisa Agropecuaria Brasileira 47, 14-21.

Mitchell, R.A.C., Mitchell, V.J., Driscoll, S.P., Franklin, J., Lawlor, D.W., 1993. Effects of increased $\mathrm{CO}_{2}$ concentration and temperature on growth and yield of winter wheat at two levels of nitrogen application. Plant, Cell and Environment 16, 521-529.

Morecroft, M.D., Paterson, J.S., 2006. Effects of temperature and precipitation changes on plant communities. In: Morison, J.I.L., Morecroft, M.D. (Eds.), Plant Growth and Climate Change. Blackwell Publishing Ltd, Oxford, UK, 146-164.

Nobel, P., 2005. Physicochemical and Environmental Plant Physiology. $3^{\text {rd }}$ edition, Academic Press, San Diego, California.

Norby, R.J., Luo, Y., 2004. Evaluating ecosystem responses to rising atmospheric $\mathrm{CO}_{2}$ and global warming in multifactor world. New Phytologist 162, 281-293.

Paknejad, F., Pad, P.F., Ilkaee, M.N., Fazeli, F., 2012. Simulation of soybean growth under sowing date management by CROPGRO model. American Journal of Agricultural and Biological Sciences 7(2), 143-149.

Prasad, P.V.V., Allen Jr, L.H., Boote, K.J., 2005. Crop responses to elevated carbon dioxide and interaction 
with temperature: grain legumes. Journal of Crop Improvement 13(1-2), 113-155.

Puteh,A.B.,ThuZar, M., Monjurul, M., Mondal, A., Abdullah, N.A.P.B., Halim, M.R.A., 2013. Soybean [Glycine max (L.) Merrill] seed yield response to high temperature stress during reproductive growth stages. Australian Journal of Crop Science 7(10), 1472-1479.

Singh, R., Singh, D., Shekhar, C., Mani, J.K., 2010. Evaluation of 'SOYGRO' model for soybean crop under Hisar conditions. Journal of Agrometeorology 12(1), 121122.

Singh, A., Jasrai, Y.T., 2012. Response of crops to elevated atmospheric carbon dioxide.Proceedings of the Indian National Science Academy 78(1), 45-49.

Trnka, M., Dubrovsky, M., Semeradova, D., Zalud, Z., 2004. Projections of uncertainties in climate change scenarios into expected winter wheat yields. Theoretical and Applied Climatology 77, 229-249.

Ziska, L.H., Bunce, J.A., 2006. Plant responses to rising atmospheric carbon dioxide. In: Morison, J.I.L., Morecroft, M.D. (Eds.), Plant growth and climate change. Blackwell Publishing Ltd, Oxford, UK, 17-47. 